\title{
Production of Conidia by Entomopathogenic Fungi and Their Pathogenicity Against Coptotermes sp.
}

\author{
Deni Zulfiana*, Apriwi Zulfitri, Anis Sri Lestari, Ni Putu Ratna Ayu Krishanti, Dita Meisyara \\ Research Center for Biomaterials, Indonesian Institute of Sciences-LIPI. Indonesia \\ *Email: zulfiana@biomaterial.lipi.go.id
}

Submitted: 11 December 2019. Revised: 11 February 2020. Accepted: 20 March 2020

\begin{abstract}
Entomopathogenic fungi have the potential to infect most arthropods including termites which are economically important major insect pests of wood, wood products and building structures. However, the application of this fungus in the field has not shown satisfactory results yet, one of which is constrained in mass production of conidia. The purpose of this study was to evaluate 16 types of biodegradable products and waste as substrates for mass production of conidia using solid state fermentation method and two types of inoculum (solid and liquid inoculum). Toxicity tests were carried out on subterranean termites (Coptotermes sp.) based on JIS K 1571, 2010. The parameters observed were the number and dry weight of the conidia produced, conidial viability, nutrient content of the substrate, and percentage of termite mortality. The results showed that rice, sorghum and corn were the best media for the growth of entomopathogenic fungi based on the number of conidia and dry weight of the conidia produced. Metarhizium sp. T4.B23 produced the highest number of conidia, $1.12 \times 10^{11}$ conidia $/ 100 \mathrm{~g}$ substrate and yielded $180.9 \pm 0.623 \mathrm{~g}$ dry conidia/kg of rice; followed by Metarhizium sp. B2.2 grown on sorghum that resulted in $1.11 \times 10^{10}$ conidia $/ 100 \mathrm{~g}$ substrates and $127.8 \pm 0.570 \mathrm{~g} / \mathrm{kg}$ sorghum; and $B$. bassiana produced $8.3 \times 10^{9}$ conidia/100 g substrate and $31.24 \pm 0.407 \mathrm{~g} / \mathrm{kg}$ sorghum. Metarhizium sp. B2.2 showed the highest toxicity to termites with $100 \%$ mortality that was observed within the second day of testing. The novelty of this research is we found two strains of Metarhizium indigenous Indonesia (T4.B23 and B2.2) that isolated from soil in Wangameti, Sumba, East Nusa Tenggara and Mount Gandang Dewata, West Sulawesi, respectively. In this study we not only can produce the high number of conidia from these fungi using cheap media but also it has high toxicity to termites. Furthermore, the conidia of these fungi are very potential to be developed as a biopesticide for termite control, so the use of chemical pesticides can be reduced.
\end{abstract}

Keywords: Beauveria, biopesticide, Coptotermes, entomopathogenic fungi, Metarhizium

How to Cite: Zulfiana, D., Zulfitri, A., Lestari, A. S., Krishanti, N. P. R. A., \& Meisyara, D. (2020). Production of Conidia by Entomopathogenic Fungi and Their Pathogenicity Against Coptotermes sp. Biosaintifika: Journal of Biology \& Biology Education, 12 (1), 1-9

DOI: http://dx.doi.org/10.15294/biosaintifika.v12i1.22435

\section{INTRODUCTION}

Coptotermes is a genus of subterranean termite group within family Rhinotermitidae. Genus Coptotermes' habitats are widespread in temperate, subtropical and tropical areas (Evans, 2013). Aside for being one of the most efficient lignocellulose decomposers, C. formosanus and C. gestroi have been recorded as major invasive pests to unprotected wooden constructions and building especially those that contain lignocellulosic materials (Chouvenc, et al., 2015; Tarmadi et al., 2017). In the US alone, economic loss due to termite infestation on man-made structures reached $\$ 5$ billion annually (Peterson, 2010). There are four different methods to control the insect pests including chemical, mechanical, physical and biological pest-control methods (Indriyanti et al., 2017). However, up to now synthetic chemical termiticide still provides the most efficient and long term solution against termite attack. Types of termite management including pre and post construction, soil treatment and population control are mostly using harmful chemicals classified as Persistent Organic Pollutants
(POPs) such as aldrin, coldrane, dieldrin, endrin, etc. (UNEP, 2008). Those chemicals are considered prohibited as pesticide properties due to resistance to degradation thus causing hazardous effects to human and ecosystem. Less toxic chemicals have been used to replace them even though their toxicity still dangerous for non-target insect (Su et al., 2012).

As an alternative to chemical insecticides, biopesticide derived from entomopathogenic fungi have become widely investigated to eliminate local infestations. However, the application method is still being developed because of the nature of termite colonies to avoid infected termite or areas therefore reduce the possibility of epizootic within the colony, especially in subterranean termite (UNEP, 2008; Chouvenc \& Su, 2012). Efficiently, the cadaver of infected termite will be immediately cannibalized or buried after being covered with fungistatic materials such as fecal pellets and saliva of termite (Chouvenc $\& \mathrm{Su}, 2012)$. For that reason, instead of endless work on finding the most virulent fungal against termite, research should be more focused on developing better 
formulation and methods for pathogens efficacy in field (Milner, 2003).

A suitable formulation is important to ensure successful utilization and consistent quality of the marketed material throughout the mass-production process (Brownbridge et al., 2001) for example long shelf life and fungal efficacy. In this sense, virulence stability is clearly a desirable trait for a massproduced biocontrol agent (Ansari \& Butt, 2011). An effective incubation conditions in fungal mass production should be applied in order to maintain conidial virulence as explained by Lopez-Perez et al. (2015). Carrier selection is another key factor to maintain and deliver the virulency of main actor of biopesticides when applied on the target. Selecting the right carrier is important since their physico-chemical properties that should not only support the fungal growth for mass production and preserve high survival rate under storage condition but also contribute to the biopesticide formulation efficacy (Kumar et al., 2014).

Entomopathogenic fungi are able to grow on wide range of biodegradable substrates although the most commonly conidial production media selected has been rice grain due to its desired physical characteristics including homogeneity particle size to support a stable production of conidia and structural integrity even after colonization by fungal mycelia (Lopez-Perez et al., 2015). Meanwhile, the use of agroindustrial residues or waste as substrate for production of conidia has been gaining attraction because of the benefits offered such as low cost materials, locally available and derived from nonedible source. Several previous studies have mass produced conidia of entomopathogenic fungi from non grain-based agroproducts as alternatives to grainbased substrate in solid-state fermentation such as rejected raw potato and raw banana (Thakre et al., 2011), rice husk and sugarcane bagasse (Mascarin et.al., 2010), farm yard manure and sugar industry press mud (Prasad \& Pal, 2014), jack seed and sawdust (Sahayaraj \& Namasivayam, 2008) tea leaf waste, wheat bran, and seed cake of jatropha (Mishra et al., 2016). Even though the use of agricultural waste is considered economical, infection rate of the end product should not be compromised. This study explored a wide rage of biodegradable substrates including grains, cellulosic biomass and agro industrial residues as substrate for spore production of entomopathogenic fungi isolates and also investigated their efficacy against Coptotermes sp.

The purpose of this study was to evaluate some types of biodegradable products and waste as substrates for mass production of conidia using solid state fermentation method and two types of inoculum namely solid and liquid inoculum. The result of this study can provide information to the society about the best media that can be used for mass-production of entomopathogenic fungi to be developed as biopesticides, so the use of chemical pesticides can be reduced.

\section{METHODS}

\section{Microorganisms and Inoculum Preparation of the Entomopathogenic Fungi}

The entomopathogenic fungi isolates used in this study were Beauveria bassiana from Bogor Agricultural University Culture Collection (IPBCC), $\mathrm{Me}$ tarhizium T4.B23 isolated from soil in Wangameti, Sumba, East Nusa Tenggara and Metarhizium B2.2 isolated from soil of Mount Gandang Dewata, West Sulawesi. The isolates were subcultured on potato dextrose agar (PDA) for 7 days. In this study, two types of inoculums were used: solid inoculums that were grown on PDA media in petri dishes for 7 days and liquid inoculums grown in potato dextrose broth (PDB) media and shaking continuously (120 rpm, 28 $\left.{ }^{\circ} \mathrm{C}\right)$ for 3 days.

\section{Preparation of Fungal Growth Substrate}

In order to select the best entomopathogenic fungal growth substrate, the study screened 16 types of biodegradable substrates included rice, corn, sorghum, soybean, rice husk, rice bran, sugarcane bagasse, sorghum stalk, rice straw, corn stalk, oil palm empty fruit bunches (OPEFB), sawdust of Albizia chinensis, sawdust of Tectona grandis, sawdust of Hevea brasiliensis, sawdust of bamboo and coconut fiber. Rice grain, corn and shorgums were previously softened by steaming for 1 hour before sterilization process. The substrate were then weighed $100 \mathrm{~g}$ and sterilized at $121{ }^{\circ} \mathrm{C}, 1.5$ atm for 15 minutes. After cooled down, each substrates were inoculated with solid and liquid inoculum, respectively. Solid inoculum used was 3 plugs of $6 \mathrm{~mm}$ mycelial agar, while 1 $\mathrm{ml}$ fungal culture in PDB used as liquid inoculum. Inoculated substrates were then incubated at $25^{\circ} \mathrm{C}$ for 14 days.

\section{Determination of Conidia Concentration}

Conidial number was counted after incubation period by mixing $1 \mathrm{~g}$ of fully colonized substrate into $100 \mathrm{~mL}$ of water + tween 80 and vortexed for 5-10 minutes to remove conidia that were attached to the surface of the substrate. Conidia were counted using haemocytometer under microscope at 400 magnification. The number of conidia was determined using the formula by Nuryanti et al. (2012) as follow:

$$
I=\frac{t \times d}{0.25 \times n} \times 10^{6}
$$


Table 1. The number of conidia of entomopathogenic fungi in 100g growth substrate inoculated with solid and liquid inoculum

\begin{tabular}{|c|c|c|c|c|c|c|}
\hline \multirow{2}{*}{$\begin{array}{l}\text { Growth } \\
\text { strate }\end{array}$} & \multicolumn{2}{|l|}{ B. bassiana } & \multicolumn{2}{|c|}{ Metarhizium sp. T4.B23 } & \multicolumn{2}{|c|}{ Metarhizium sp. B2.2 } \\
\hline & PDA & PDB & PDA & PDB & PDA & PDB \\
\hline Rice & $5.35 \times 10^{9}$ & $8.3 \times 10^{9}$ & $1.06 \times 10^{10}$ & $1.12 \times 10^{11}$ & $1.06 \times 10^{10}$ & $1.11 \times 10^{10}$ \\
\hline Corn & $1.5 \times 10^{7}$ & $2.45 \times 10^{7}$ & $5.9 \times 10^{9}$ & $9 \times 10^{9}$ & $8.5 \times 10^{9}$ & $2.3 \times 10^{9}$ \\
\hline Sorghum & $7.8 \times 10^{9}$ & $7.7 \times 10^{9}$ & $1.19 \times 10^{10}$ & $1.19 \times 10^{10}$ & $8.65 \times 10^{9}$ & $8.95 \times 10^{9}$ \\
\hline Soybean & $7.7 \times 10^{6}$ & $6.15 \times 10^{6}$ & $4.5 \times 10^{3}$ & $4.5 \times 10^{3}$ & $5 \times 10^{3}$ & $7 \times 10^{3}$ \\
\hline Rice bran & $2.85 \times 10^{4}$ & $2.65 \times 10^{4}$ & $3.7 \times 10^{5}$ & $5.5 \times 10^{5}$ & $7.05 \times 10^{5}$ & $6 \times 10^{5}$ \\
\hline Rice husk & $2.3 \times 10^{5}$ & $3.35 \times 10^{5}$ & $5.1 \times 10^{4}$ & $2.85 \times 10^{4}$ & $7.5 \times 10^{4}$ & $5.5 \times 10^{4}$ \\
\hline Bagasse & $3.5 \times 10^{5}$ & $2.5 \times 10^{5}$ & $9 \times 10^{5}$ & $3.5 \times 10^{5}$ & $2.5 \times 10^{5}$ & $2.5 \times 10^{5}$ \\
\hline Sorghum stalk & $8 \times 10^{6}$ & $1.4 \times 10^{6}$ & $7 \times 10^{6}$ & $9 \times 10^{6}$ & $9 \times 10^{6}$ & $2 \times 10^{6}$ \\
\hline Rice straw & $3.2 \times 10^{5}$ & $1.5 \times 10^{5}$ & $7.5 \times 10^{5}$ & $1 \times 10^{5}$ & $4 \times 10^{5}$ & $5.5 \times 10^{5}$ \\
\hline Corn stalk & $2.3 \times 10^{7}$ & $2.1 \times 10^{7}$ & $3.65 \times 10^{7}$ & $1.9 \times 10^{7}$ & $5.8 \times 10^{7}$ & $1.35 \times 10^{7}$ \\
\hline OPEFB & $9 \times 10^{4}$ & $6.5 \times 10^{4}$ & $4 \times 10^{5}$ & $3 \times 10^{5}$ & $5.5 \times 10^{5}$ & $3 \times 10^{5}$ \\
\hline $\begin{array}{l}\text { Sawdust of } \\
\text { A.chinensis }\end{array}$ & $2.5 \times 10^{5}$ & $6 \times 10^{5}$ & $8 \times 10^{5}$ & $1.05 \times 10^{5}$ & $3.5 \times 10^{5}$ & $2.5 \times 10^{5}$ \\
\hline $\begin{array}{l}\text { Sawdust of } \\
\text { T. grandis }\end{array}$ & $3.5 \times 10^{4}$ & $6.5 \times 10^{4}$ & $1.9 \times 10^{5}$ & $3.5 \times 10^{5}$ & $4.5 \times 10^{5}$ & $5 \times 10^{5}$ \\
\hline $\begin{array}{l}\text { Sawdust of } \\
\text { H. brasiliensis }\end{array}$ & $5 \times 10^{4}$ & $6 \times 10^{4}$ & $1.8 \times 10^{5}$ & $8 \times 10^{5}$ & $2 \times 10^{5}$ & $6 \times 10^{5}$ \\
\hline $\begin{array}{l}\text { Sawdust } \\
\text { of bamboo }\end{array}$ & $2 \times 10^{6}$ & $1.65 \times 10^{6}$ & $1.55 \times 10^{6}$ & $8 \times 10^{6}$ & $3.7 \times 10^{6}$ & $6.5 \times 10^{6}$ \\
\hline Coconut fiber & $4 \times 10^{4}$ & $4 \times 10^{4}$ & $3 \times 10^{5}$ & $3 \times 10^{5}$ & $3 \times 10^{5}$ & $2.5 \times 10^{5}$ \\
\hline
\end{tabular}

According to Sahayaraj and Namasivayam (2008), the success of controlling insect pests by microorganisms depends not only on their isolation, characterization and pathogenicity, but also on the mass production of microbial agents in the laboratory. Additionally, for a successful integrated pest management program, the carrier of the biological agents such as entomopathogenic fungi must be easy to obtain and inexpensive such as rice grain. Therefore, as stated by Roshandel et al. (2016) rice is the best substrate to support the growth and development of fungi to get high numbers of conidia of entomopathogenic fungi, while other cereals can also be used as alternatives.

\section{Proximate Analysis of Growth Substrate}

Based on the proximate analysis, nutrient content of the three best growth substrates namely rice, sorghum and corn (Figure 2) is listed in Table 3. All tested grains have a high carbohydrate and protein content, which are the main elements needed for fungal growth and conidia production. Tested rice grain contains $9.14 \%$ protein and $72.9 \%$ carbohydrate, sorghum contains $7.44 \%$ protein and $79.1 \%$ carbohydrate, while corn contains $10.9 \%$ protein and $65 \%$ carbohydrate.

Table 2. Average of conidial dried weight harvested from 3 growth substrate

\begin{tabular}{lccc}
\hline \multirow{2}{*}{ Growth Substrate } & \multicolumn{3}{c}{ Average of conidial dried weight (g/kg substrate) } \\
\cline { 2 - 4 } & B. bassiana & Metarhizium T4.B23 & Metarhizium B2.2 \\
\hline Rice & $30.16 \pm 0.236$ & $180.9 \pm 0.623$ & $122.84 \pm 0.461$ \\
Corn & $17.84 \pm 0.134$ & $39.01 \pm 0.091$ & $34.19 \pm 0.372$ \\
Sorghum & $31.24 \pm 0.407$ & $167.71 \pm 0.580$ & $127.8 \pm 0.570$ \\
\hline
\end{tabular}




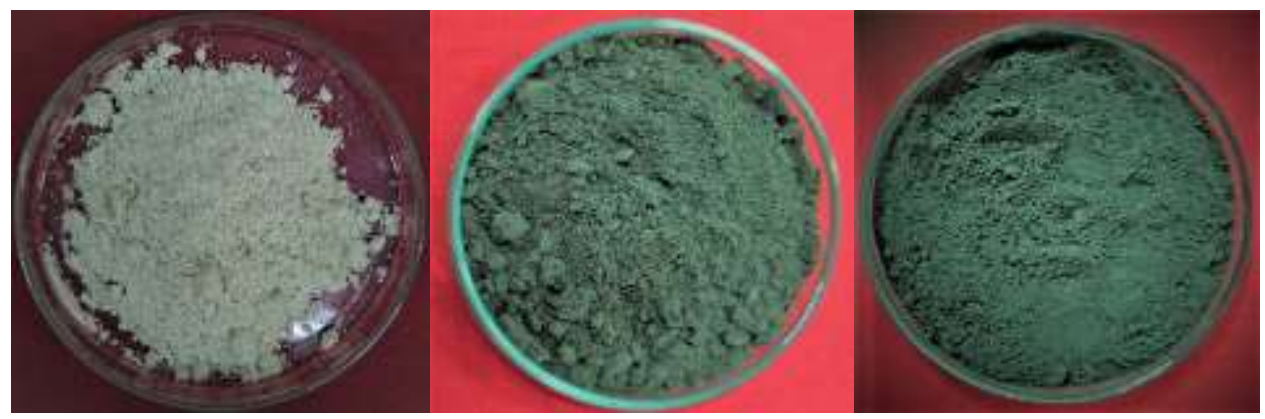

Figure 1. Appereance of harvested conidial grown on rice. B. bassiana (left), Metarhizium T4.B23 (middle) and Metarhizium B2.2 (right).

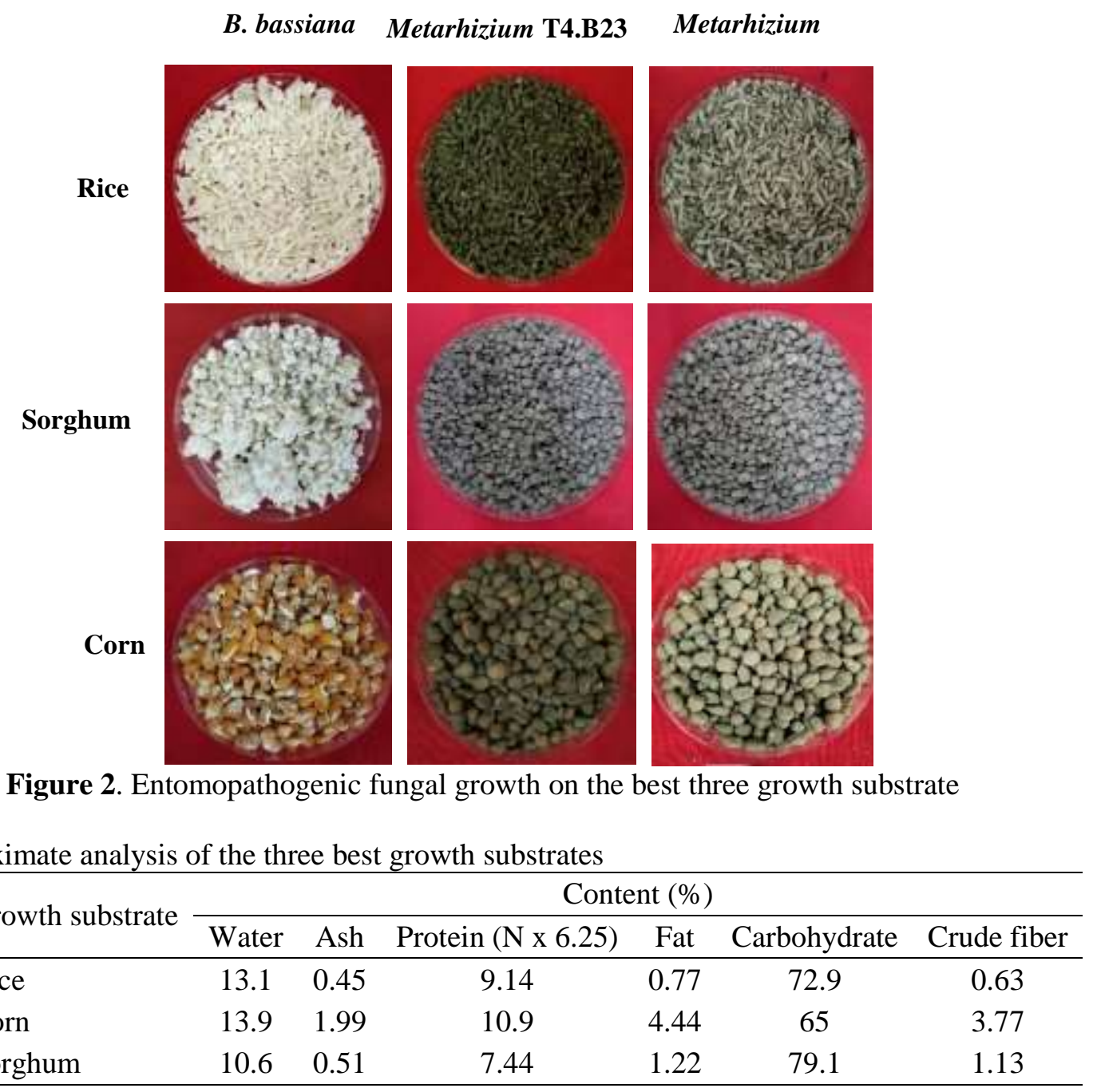

Table 3. Proximate analysis of the three best growth substrates

\begin{tabular}{lcccccc}
\hline \multirow{2}{*}{ Growth substrate } & \multicolumn{6}{c}{ Content (\%) } \\
\cline { 2 - 7 } & Water & Ash & Protein $(\mathrm{N} \times 6.25)$ & Fat & Carbohydrate & Crude fiber \\
\hline Rice & 13.1 & 0.45 & 9.14 & 0.77 & 72.9 & 0.63 \\
Corn & 13.9 & 1.99 & 10.9 & 4.44 & 65 & 3.77 \\
Sorghum & 10.6 & 0.51 & 7.44 & 1.22 & 79.1 & 1.13 \\
\hline
\end{tabular}

According to FAO (2004), rice provides high carbohydrate but low protein content. A hundred gram of rice contains 79.34 grams of carbohydrates, 0.58 grams of fat and 6.6 grams of protein. Rice is also known to be one of the good mediums for growth of $B$. bassiana, because rice contains a staple carbohydrate. Protein and carbohydrates are needed by fungi for vegetative growth and conidia formation, thus formed conidia will germinate faster and have high virulence if carbohydrate and protein requirements are met (Mishra, et al., 2016).
Nutritional sources can affect growth, sporulation and virulence of the insect pathogenic fungus (Islam et al., 2019). A fairly dominant protein and carbohydrate content in half cooked rice is likely to influence the amount of conidia produced while macro elements such as oxygen, sulfur, and phosphate are the main components of nutrients needed by fungi (Indrayani $\&$ Prabowo, 2010). In addition, the surface area of the growth substrate also affects the amount of conidia produced by the fungus. The wider surface area of the substrate, the more conidia will be produced. Substrate that tend to clot will have a narrow surface area, 
so that conidia production will be less (Susilawati, 2015).

\section{Viability Test of Entomopathogenic Fungal Conidia}

Viability test showed that entomopathogenic fungus conidia were still viable from 1 to 6 months storage in $4{ }^{\circ} \mathrm{C}$ refrigerator which verified by germination test on PDA media (Table 4). In this study, after being stored for six months, the three strains of entomopathogenic fungus demonstrated percentage of germination up to $10^{5}-10^{9} \mathrm{CFU} / \mathrm{ml}$ despite a decrease in conidial density.

Table 4. Viability test of B. bassiana, Metarhizium sp. T4.B23 dan Metarhizium sp. B2.2 during 6 month storage

\begin{tabular}{lccc}
\hline Storage time & B. bassiana $(\mathrm{CFU} / \mathrm{ml})$ & Metarhizium sp. T4.B23 (CFU/ml) & Metarhizium sp. B2.2 (CFU/ml) \\
\hline 1 month & $3.7 \times 10^{7}$ & $5.4 \times 10^{10}$ & $7.6 \times 10^{10}$ \\
2 months & $2.1 \times 10^{7}$ & $1.2 \times 10^{9}$ & $2.7 \times 10^{9}$ \\
3 months & $1.1 \times 10^{6}$ & $5.1 \times 10^{9}$ & $2.1 \times 10^{9}$ \\
4 months & $11.2 \times 10^{5}$ & $4.4 \times 10^{9}$ & $4.8 \times 10^{9}$ \\
5 months & $7.2 \times 10^{5}$ & $4.7 \times 10^{9}$ & $5.2 \times 10^{9}$ \\
6 months & $3.2 \times 10^{5}$ & $1.7 \times 10^{9}$ & $3.2 \times 10^{9}$ \\
\hline
\end{tabular}
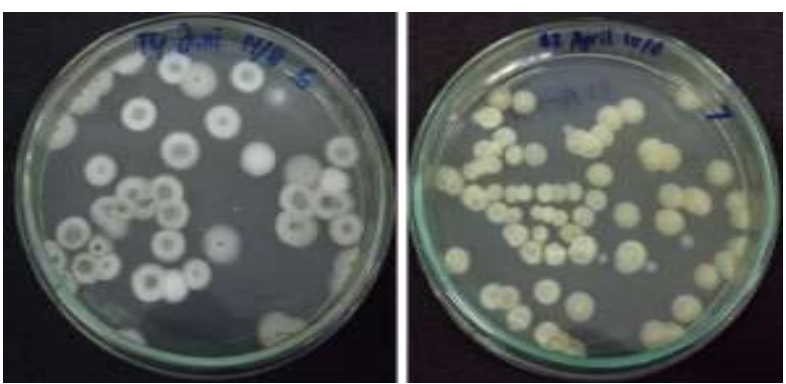

Figure 3. Germination test of Metarhizium sp. B2.2 after 4 months storage (left) and Metarhizium sp. T4B23 after 2 months storage (right)

\section{Toxicity of Entomopathogenic Fungal Conidia against Subterranean Termites (Coptotermes sp.)}

The efficacy of tested entomopathogenic fungus conidia grown on rice media against subterrranean termites was carried out using two methods; spray and bait method for 14 days of treatment. The percentage of termite mortality is shown in Figure 4 where all three strains of entomopathogenic fungus; B. bassiana, Metarhizium sp. T4.B23 and Metarhizium sp. B2.2 demonstrated a high pathogenicity against subterranean termites using either spray or bait method.

On spray method, the conidia of Metarhizium sp. B2.2 was effective in killing $100 \%$ termite on the $2^{\text {nd }}$ day of testing, while conidia of Metarhizium sp. T4.B23 and B. bassiana obtained 100\% mortality percentage on the $4^{\text {th }}$ and $6^{\text {th }}$ day of testing, respectively. Similar pattern was shown by the results of bait method, Metarhizium sp. B2.2 showed the highest toxicity followed by Metarhizium sp. T4.B23 and $B$. bassiana. Percentage of termite mortality treated with Metarhizium sp. B2.2 reached $100 \%$ on the $10^{\text {th }}$ day, while Metarhizium sp. T4.B23 killed $100 \%$ baited termite on the $12^{\text {th }}$ day testing. Lastly, $B$. bassiana promoted $96.45 \%$ termite mortality on the $14^{\text {th }}$ day. Based on this efficacy test, Metarhizium was more effective and more toxic against Coptotermes sp. compared to B. bassiana. This is supported by study from Sileshi et al., (2013) showing that $B$. bassiana (PPRC-56 and 9609) were less effective in controlling Macrotermes sp. resulted in percentage of mortality between $25-95 \%$ and $\mathrm{LT}_{50}$ in 8.8 days compared with $M$. anisopliae isolates (PPRC-2 and $\mathrm{MM}$ ) killed $60-100 \%$ tested termites and $\mathrm{LT}_{50}$ value was 7.74 days.

When comparing the effectiveness of the two efficacy methods used, it appears that spray method is more effective than bait method. The fungal conidia kill termites faster, i.e. $100 \%$ of termite mortality within 2 days of testing in Metarhizium sp. B2.2 treatment. Meanwhile, bait method obtained $100 \%$ mortality of termites starting on the $10^{\text {th }}$ day after the treatment. This is due to the characteristics of the entomopathogenic fungus that starting the infection via insect cuticle which is different from the entomopathogenic bacteria that attack through oral toxicity.

Entomopathogenic fungi such as $M$. anisopliae infect their host through the mechanism of attaching conidia to the cuticle of the larvae then germinates and form hyphae to penentrate the insect body. The hyphae will grow deeper into tissues in the body of host by releasing enzymes such as proteases, lipolytics, chitinases and others to penetrate the cuticle. After that, M. anisopliae fungal hyphae will attack the 
host larvae by absorbing body fluids until the host dies and the body hardens. In addition, $M$. anisopliae produces larvicidal toxins such as destruxin A, B, C, $\mathrm{D}, \mathrm{E}$ and desmethyl destruxin B, cyclopeptide causing cell paralysis in the target organelle (endoplasmic reticulum, nucleus membrane, and mitochondria). Furthermore, it can cause abnormalities in the physique of the host body such as the middle gut, muscle tissue, hemocyst, and malpighi tubules (Aw \& Hue, 2017).

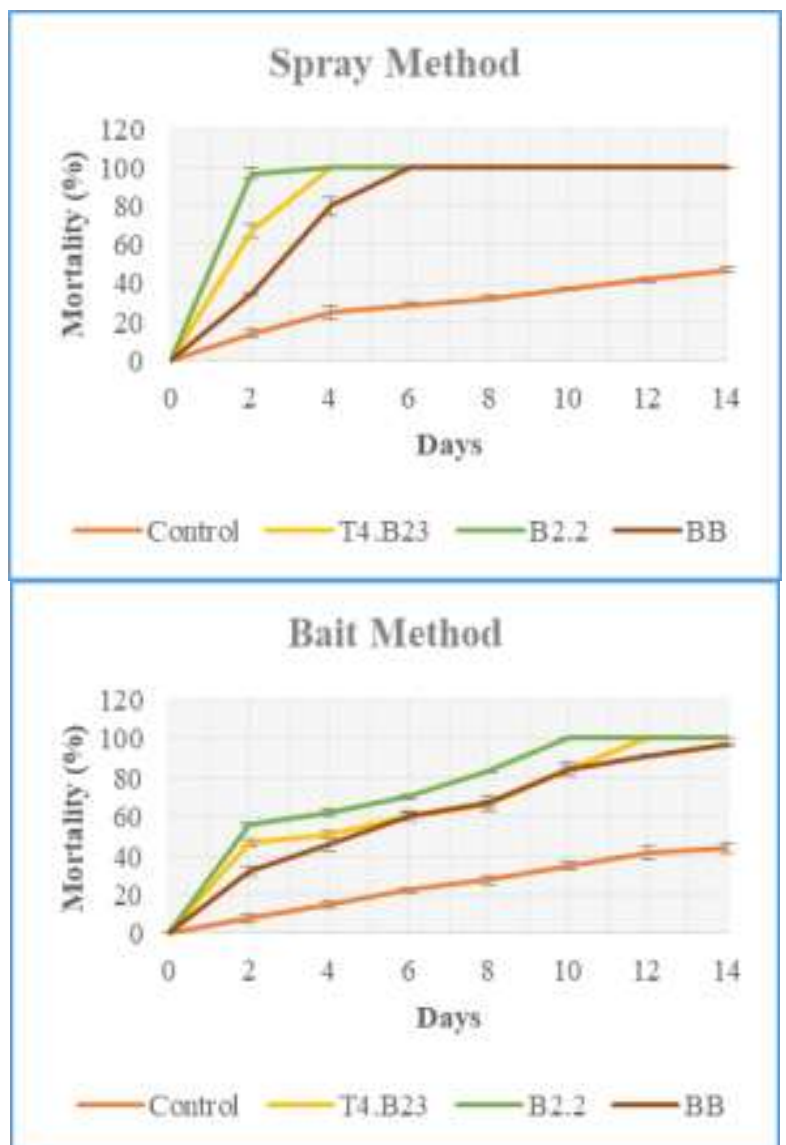

Figure 4. The efficacy of tested entomopathogenic fungus conidia grown on rice media on subterranean termites (a) spraying method (b) bait method

Meanwhile, B. bassiana has a slightly different mechanism from Metarhizium in infecting its host. According to Keswani et al., (2013), mechanism of infection of the fungus $B$. bassiana starting with hyphae or conidia that penetrate the cuticles in the insect's skin using a variety of enzymes that are able to attack the cuticle of insects such as protease, lipolytic, amylase, and chitinase. Mechanically, the infection can also occur by pressure from the increasing biomass of $B$. bassiana conidium. It starts with the penetration of $B$. bassiana mycelium in the cuticle and apresorium is formed to go through the epidermis and hypodermis. Hyphae that have entered the insect's body will attack the tissue and can multiply in the insect's heamolymph. When the $B$. bassiana fungus is already present in the host's body (target insect), the fungus will produce toxic chemicals such as beauvericin, beauverolide, isorolide, dyes and oxalic acid (Vikhe et al., 2016). Beauvaricin is a poison that causes paralysis, insects will lose coordination in the motion system which causes random movements which then weakened the host and eventually lead to death. These chemicals also have disruptive effects on the respiratory and nerve system, damage the digestive tract and so on (Wahyudi, 2008). Also, according to Wahyudi (2008), after $B$. bassiana succeeds in killing its host, it will be saprophytic fungi. Additionally, B. bassiana will release Oosporein substances (antibiotics) that infecting bacteria in the body of the host, so that the growth of B. bassiana will spread to all parts of the host body until the mycelium come out from the host body. The fungus growth on the outside of the host body will then form conidia and spread to the surrounding environment to infect new insects target.

The novelty of this research is we found two strains of Metarhizium indigenous Indonesia (T4.B23 and B2.2) that isolated from soil in Wangameti, Sumba, East Nusa Tenggara and Mount Gandang Dewata, West Sulawesi. In this study we not only can produce the high number of conidia from these fungi using cheap media but also it has high toxicity to termites. Furthermore, the conidia of these fungi are very potential to be developed as a biopesticide for termite control, so the use of chemical pesticides can be reduced.

\section{CONCLUSION}

Rice, sorghum dan corn were the best growth media for entomopathogenic fungi tested (Metahizium sp. T4.B23, Metahizium sp. B2.2 and B. Bassiana) based on the number and weight of conidia produced. Metahizium sp. T4.B23 produced the highest number of conidia of all while Metahizium sp. B2.2 showed the highest pathogenicity against subterrranean termites compared to other fungal tested.

\section{ACKNOWLEDGEMENT}

Authors thank Program Tematik DIPA for funding this research and Sundari from University of Lampung for technical assistant in the laboratory.

\section{REFERENCES}

Ansari, M., \& Butt, T. (2011), Effects of successive subculturing on stability, virulence, conidial yield, germination and shelf life of entomopathogenic fungi. Journal of Applied Microbiology, 110, 1460-1469. 
Aw, K.M.S., \& Hue, S.M. (2017). Review: Mode of infection of Metarhizium spp. fungus and their potential as biological control agents. J. Fungi, 3, 30.

Bich, G. A., Casrtillo, M.L., Villalba, L. L., \& Zapata, P. D. (2018). Evaluation of rice by-products, incubation time, and photoperiod for solid state mass multiplication of the biocontrol agents Beauveria bassiana and Metarhizium anisopliae. Agronomy Research, 16(5), 1921-1930.

Brownbridge, M., Costa, S., \& Jarnoski S.T. (2001). Effects of in vitro passage of Beauveria bassiana on virulence to Bemisia argentifolii. J. Invertebr Pathol., 77, 280-283.

Chouvenc, T., \& Su, N.Y. (2012). When subterranean termites challenge the rules of fungal epizootics. PloS one. 7(3), 34484.

Chouvenc, T., Helmick, E.E., \& Su, N.Y. (2015). Hybridization of two major termite invaders as a consequence of human activity. PLoS One, 10, 0120745.

Evans, T.A., Forschler, B.T., \& Grace J.K. (2013). Biology of invasive termites: a worldwide review. Annual Review of Entomology, 58, 455-474

FAO. (2004). Statistical Database of Food Balance Sheet. Retrieved from http://www.fao.org. (Accessed on 3 November 2018).

Indrayani, I.G.A.A., \& Prabowo. (2010). Pengaruh komposisi media terhadap produksi konidia jamur entomopatogen Beauveria bassiana (Balsamo) Vuillemin. Buletin Tanaman Tembakau, Serat \& Minyak Industri. 2(2). ISSN: 2085-6717, 88-94.

Indriyanti, D.R., Nuraini, I., \& Slamet, M. (2017). The effect of water content of medium containing Oryctes rhinoceros larvae on Metarhizium anisopliae pathogenicity. Biosaintifika, 9(2), 363-369.

Islam, T., Gupta, D.R., Surovy, M.Z., Mahmud, N.U., Mazlan, N., \& Islam, T. (2019). Identification and application of a fungal biocontrol agent

Cladosporium cladosporioides against Bemisia tabaci. Biotechnology \& biotechnological equipment, 33(1), 1698-1705.

Test methods for determinating effectiveness of wood preservatives and their performance requirements, [JIS] Japanese Industrial Standard, JIS K 15712010; Japanese Standard Association: Tokyo, Japan, 2010.

Keswani, C. Singh, S.P., \& Singh, H.B. (2013). Beauveria bassiana: Status, mode of action, applications and safety issues. Biotech Today, 3(1), 1620

Kumar, S., Roy, P.D., Lal, M., Chand, G., \& Singh, V. (2014). Mass Multiplication and shelf life of Trichoderma species using various agroproducts. An International Quarterly Journal of Life Sciences, 9, 1143-1145.
Lopez-Perez, M, Rodríguez-Gomez, D., \& Loera, O. (2015). Production of conidia of Beauveria bassiana in solid-state culture: Current status and future perspectives. Critical reviews in biotechnology, 35(3), 334-341.

Mascarin, G.M., Alves, S.B., \& Lopes, R.B. (2010). Culture media selection for mass production of Isaria fumosorosea and Isaria farinosa. Brazilian Archives of Biology and Technology, 53(4), 753761.

Me'ndez-Gonza'lez, F., Loera-Corral, O., SaucedoCastan eda, G., \& Favela-Torres, E. (2017). Current developments in biotechnology and bioengineering: Bioreactors for the production of biological control agents produced by solid-ttate fermentation. (Editor: A. Pandey, C. Larroche, C.R. Soccol, Ed.). Elsevier.

Milner, R.J., (2003). Application of biological control agents in mound building termites (Isoptera: Termitidae) - Experiences with Metarhizium in Australia. Sociobiology, 41, 419-428.

Mishra, S., Kumar, P., \& Malik, A. (2016), Suitability of agricultural by-products as production medium for spore production by Beauveria bassiana HQ917687. Int. J. Recycl. Org. Waste Agric., 5(2, 1), 179-184.

Nuryanti, N.S.P., Wibowo L., \& Azis A. (2012). Penambahan beberapa jenis bahan nutrisi pada media perbanyakan untuk meningkatkan virulensi Beauveria Bassiana terhadap hama walang sangit. J. HPT Tropika, 12(1), 64-70.

Peterson, C. (2010). Considerations of Soil-Applied Insecticides for Termite Control. Outlooks Pest. Manag. (21), 89-93.

Prasad, C.S., \& Pal, R. (2014). Mass production and economics of entomopathogenic fungus, Beauveria bassiana, Metarhizium anisopliae and Verticillium lecanii on agricultural and industrial waste, Scholars Journal of Agriculture and Veterinary, 1(1), pp. 28-32.

Roshandel, S., Askary, H., Hassanlouei, R. T., \& Allahyari, H. (2016). The effects of natural substrates on the sporulation and viability of conidia and blastospores of Metarhizium anisopliae. Biocontrol in Plant Protection, 4(1), 94-103.

Sahayaraj, K., \& Namasivayam, S.K.R. (2008). Mass production of entomopathogenic fungi using agricultural products and by products. African Journal of Biotechnology, 7. 10.5897/AJB07.778.

Sileshi, A., Sori, W., \& Dawd, M. (2013). Laboratory evaluation of entomopathogenic fungi Metarhizium anisophilae and Beauveria bassiana against termite, Macrotermes (Isoptera: Termitidae). Asian Journal of Plant Science, 12(1), 1-10. 
[SNI] Standar Nasional Indonesia, SNI 01-28911992. Cara Uji Makanan dan Minuman. Badan Standarisasi Nasional: Jakarta 1992.

Su, N.Y., Lagnaoui, A., Wang, Q., Li, X., \& Tan, S. A. (2012). Demonstration Project of Stockholm POPs Convention to Replace Chlordane and Mirex with IPM for Termite Control in China, Journal of Integrated Pest Management, 3(4), D1-D8.

Susilawati. (2015). Sporulasi dan viabilitas konidia cendawan entomopatogen Beauveria bassiana (Balsamo) Vuillemin di berbagai media tumbuh [Undergraduate thesis]. Institut Pertanian Bogor.

Tarmadi, D, Yoshimura, T., Tobimatsu, Y., Yamamura, M., Miyamoto, T., \& Miyagawa, Y., Umezawa, T. (2017). The effects of various lignocelluloses and lignins on physiological responses of a lower termite, Coptotermes

formosanus. J. Wood Sci. 63, 464-472.
Thakre, M., Thakur, M., Malik, N., \& Ganger, S. (2011). Mass scale cultivation of entomopathogenic fungus Nomuraea rileyi using agricultural products and agro wastes. Journal of Biopesticides, 4(2), 176-179.

UNEP/FAO/Global IPM Facility Expert Group on Termite and Biology Management. (2008). Finding Alternatives to Persistent Organic Pollutants (POPs) for Termite Management. United Nations Environment Programme (UNEP)

Vikhe, A. G., Dale, N.S., Umbarkar, R.B., Labade, G.B., Savant, A. R., \& Walunj, A.A. (2016). In Vitro and In Vivo Induction, and Characterization of Toxins Isolated from Beauveria bassiana. Int. J. Pure App. Biosci., 4(3), 97-103.

Wahyudi, P. (2008). Enkapsulasi propagul jamur entomopatogen Beauveria bassiana menggunakan alginat dan pati jagung sebagai produk mikoinsektisida. Jurnal Ilmu Kefarmasian Indonesia, 51-56. 